\title{
Total polyphenols from Syzygium cumini (L.) Skeels fruit extract
}

\author{
Ketylin Fernanda Migliato ${ }^{1}$, Elisângela Simões de Carvalho ${ }^{1}$, \\ Luis Vitor Silva do Sacramento 3 , João Carlos Palazzo de Mello ${ }^{4}$, André Rolim Baby², \\ Maria Valéria Robles Velasco ${ }^{2}$, Hérida Regina Nunes Salgado ${ }^{* *}$
}

\begin{abstract}
${ }^{1}$ Department of Drugs and Medicines, School of Pharmaceutical Sciences, São Paulo State University “Júlio de Mesquita Filho", 'Department of Pharmacy, School of Pharmaceutical Sciences, University of São Paulo, ${ }^{3}$ Department of Natural Substances and Toxicology, São Paulo State University "Júlio de Mesquita Filho”, ${ }^{4}$ Department of Pharmacy and Pharmacology, Maringá State University
\end{abstract}

\begin{abstract}
A precise, accurate and low cost spectrophotometric method was developed and validated for routine determination of total polyphenols, as pyrogallic acid equivalents, from the percolated and lyophilized extract of Syzygium cumini (L.) Skeels fruits. Validation was assessed experimentally and data were rigorously treated by statistical analysis. Analytical parameters were: linearity, interval (range), precision and recovery/accuracy, limit of detection ( $\mathrm{LOD}, \mu \mathrm{g} \mathrm{mL}^{-1}$ ) and limit of quantification (LOQ, $\mu \mathrm{g} \mathrm{mL}^{-1}$ ). The visible spectrophotometric method presented linearity $\left(\mathrm{r}^{2}=0.9979 \pm 0.0010\right)$ over the concentration range $0.25-7.5 \mu \mathrm{g} \mathrm{mL}^{-1}$ of standard pyrogallic acid, precision $\leq 2.918171 \%$, recovery/accuracy ranging from 96.228693 to $107.17701 \%, \mathrm{LOD}=0.21 \mu \mathrm{g} \mathrm{mL} \mathrm{m}^{-1}$ and $\mathrm{LOQ}=0.64 \mu \mathrm{g} \mathrm{mL}^{-1}$.
\end{abstract}

Uniterms: Total polyphenols. Syzygium cumini. Botanical extract. Analytical method validation. Spectrophotometry.

\begin{abstract}
Um método espectrofotométrico preciso, rigoroso e de baixo custo foi desenvolvido e validado para a determinação de polifenóis totais, utilizando-se como padrão o ácido pirogálico. O extrato dos frutos de Syzygium cumini (L.) Skeels foi preparado empregando-se o método de percolação com posterior liofilização. A validação foi executada experimentalmente e os dados foram submetidos à análise estatística. Os parâmetros analíticos considerados foram: linearidade, intervalos de precisão e de recuperação, limite de detecção $\left(\mathrm{LD}, \mu \mathrm{g} \cdot \mathrm{mL}^{-1}\right)$ e o limite de quantificação (LQ, $\left.\mu \mathrm{g} \cdot \mathrm{mL}^{-1}\right)$. O método espectrofotométrico apresentou linearidade $\left(\mathrm{r}^{2}=0,9979+0,0010\right)$ ao longo do intervalo de concentração de $0,25-7,5 \mu \mathrm{g} \mathrm{mL}^{-1}$ de ácido pirogálico, padrão de precisão menor do que 2,918171\%; recuperação/ precisão entre 96,228693 a 107,17701\%, e LD $=0,21 \mu \mathrm{g}-\mathrm{mL}^{-1}$ e LOQ $=0,64 \mu \mathrm{g} \mathrm{mL}^{-1}$.
\end{abstract}

Unitermos: Polifenóis. Syzygium cumini. Extrato vegetal. Métodos analíticos/validação. Espectrofotometria.

\section{INTRODUCTION}

Syzygium cumini (L.) Skeels (Synonym: S. jambolanum, E. jambolana) (Myrtaceae), popularly known in Brazil as "jambolão" (jambolan or java plum in English), is a native tree of the tropics, originally from India and SE Asia. It is widespread in some states of North, Northeast and Southeast Brazil (Grover et al., 2001; Migliato et al., 2006; Migliato et al., 2007, Rey-

*Correspondence: H. R. N. Salgado. School of Pharmaceutical Sciences, São Paulo State University “Júlio de Mesquita Filho", Rodovia Araraquara-Jaú, km 1 - 14801-902 - Araraquara - SP, Brazil. Email: salgadoh@fcfar.unesp.br nertson et al., 2008) and is used as a popular treatment against various diseases. In Brazil, the bark, fruits, seeds and leaves of this plant are used for the treatment of diabetes and administered in various pharmaceutical preparations (e.g., aqueous or alcoholic extract, decoctions or crude plant juice) (Braga et al., 2007). Syzygium cumini seeds have already shown hypoglycemic and antioxidant activities. A decoction of the bark is also used for dysentery and diarrhea. Moreover, Syzygium cumini has been shown to have sedative and anticonvulsant effects and a potent central nervous system depressant effect (Pepato et al., 2004). 
Syzygium species are reported to be very rich in tannins, flavonoids, essential oils, anthocyanins and others phenolic constituents (Sharma et al., 2003; Migliato et al., 2007, Reynertson et al., 2008). Scalbert (1991) reviewed the antimicrobial properties of tannins.

According to Shafi and co-workers (2002), plant extracts of Syzygium species have known antibacterial activity. In addition, Chandrasekaran and Venkatesalu (2004) showed that aqueous and methanol extracts inhibited the growth of some of the fungal microorganisms implicated in skin diseases, such as C. albicans, T. rubrum, T. mentagrophytes and M. gypseum.

The aim of this research work was to validate a routine and low cost spectrophotometric method (mainly to be used as a quality control tool) to quantify total polyphenols, as pyrogallic acid equivalents, from the percolated and lyophilized extract of fruits from Syzygium cumini (L.) Skeels.

\section{MATERIAL AND METHODS}

\section{Solvents, reagents and reference standard}

All reagents and solvents were of analytical grade and they were purchased from Merck (Germany), Sigma-Aldrich (Brazil) and LabSynth (Brazil), and used without any further purification (sodium carbonate PA-ACS, ethanol 99.5\%, Folin-Ciocalteau 2 N). Pyrogallic acid $\geq 99 \%$, from Riedel-de Haën (Sigma-Aldrich) was used as reference standard.

\section{Plant Material}

The fruits of Syzygium cumini (L) Skeels were collected during December 2006 to January 2007, in the Medicinal and Toxic Plant Garden of FCF/UNESP, Araraquara - SP, Brazil. On the same opportunity, the voucher was deposited under the number 19586 in SJRP Herbarium, Department of Botany of IBILCE-UNESP of São Jose do Rio Preto Campus, by Dr. Neusa Taroda Ranga.

\section{Preparation of Syzygium cumini (L.) Skeels extract}

Extract was obtained by percolation using Syzygium cumini fruits. The extract was prepared with $10 \% \mathrm{w} / \mathrm{v}$ of Syzygium cumini fruits in ethanol:water (1:1). Percolated extract was concentrated under reduced pressure at $40{ }^{\circ} \mathrm{C}$ and lyophilized until total solvent elimination.

\section{Total polyphenols determination}

Chemical analysis was performed at samples protected from light during dilution. Water free of carbon dio- xide was used for the experiments. Lyophilized Syzygium cumini extract was weighed, $0.750 \mathrm{~g}$, and transferred to a $250 \mathrm{~mL}$ volumetric flask completed with water.

The amount of $5 \mathrm{~mL}$ of the above mentioned dilution was filtered and transferred to a $25 \mathrm{~mL}$ volumetric flask. To a $5 \mathrm{~mL}$ of the last solution was added $2 \mathrm{~mL}$ of FolinCiocalteau $2 \mathrm{~N}$ and diluted to $50 \mathrm{~mL}$ with sodium carbonate solution $10 \% \mathrm{w} / \mathrm{v}$. Absorbance (A1) was achieved at $757.0 \mathrm{~nm}$ after $3 \mathrm{~min}$ of the addition of the last reagent. Water was considered the blank (Farmacopéia, 1988).

\section{Analysis of polyphenols not-absorbed by skin powder}

An amount of $20 \mathrm{~mL}$ of the lyophilized extract solution in water was filtered and added of $0.2 \mathrm{~g}$ skin powder. Vigorous agitation during $60 \mathrm{~min}$ was used to assure homogenization and, then, dispersion was filtered. $5 \mathrm{~mL}$ of the filtered solution was diluted in $25 \mathrm{~mL}$ of water. An amount of $5 \mathrm{~mL}$ of the last solution was added of $2 \mathrm{~mL}$ FolinCiocalteau $2 \mathrm{~N}$ and diluted to $50 \mathrm{~mL}$ with sodium carbonate solution $10 \% \mathrm{w} / \mathrm{v}$. Absorbance (A2) was registered at 757.0 $\mathrm{nm}$ after $3 \mathrm{~min}$ of the addition of the last reagent. Water was considered the blank (Farmacopéia, 1988).

\section{Reference standard stock solution}

$50 \mathrm{mg}$ of standard pyrogallic acid was diluted in 50 $\mathrm{mL}$ of water, following, $5 \mathrm{~mL}$ of this solution was transferred to a $100 \mathrm{~mL}$ volumetric flask completed with water. To $5 \mathrm{~mL}$ of the last solution, $2 \mathrm{~mL}$ of Folin-Ciocalteau $2 \mathrm{~N}$ were assed, being then diluted to $50 \mathrm{~mL}$ with sodium carbonate solution $10 \% \mathrm{w} / \mathrm{v}$. Absorbance (A3) was obtained at $757.0 \mathrm{~nm}, 3 \mathrm{~min}$ after of the addition of the last reagent and within 15 min of the standard pyrogallic acid dilution. Water was considered the blank.

Total polyphenols were calculated according to Equation 1 (Farmacopéia, 1988):

$\mathrm{TP}=\frac{13.12\left(A_{1}-A_{2}\right)}{A_{3} \cdot m}$

EQUATION 1 - Total polyphenols (TP, in g) from Syzygium cumini fruit extract. m: mass of the sample (g); A1: absorbance of total polyphenols from the extract; A2: absorbance of polyphenols not-absorbed by skin powder from the extract; A3: absorbance of standard.

\section{Analytical curve and linearity}

Standard pyrogallic acid was diluted in the range of 
concentrations from 0.25 to $7.5 \mu \mathrm{g} \cdot \mathrm{mL}^{-1}$. The absorbance measurements were obtained at $757.0 \mathrm{~nm}$ using Spectrophotometer Hewlett Packard with a $1 \mathrm{~cm}$ quartz cuvette. Mean of eight replicates of each concentration value was employed to construct the analytical curve (Causon, 1997; Beer et al., 2003; Rolim et al., 2005).

The linearity was analyzed and confirmed by statistical analysis (Mulholland, Hibbert, 1997; Brasil, 2003; USP, 2003; Baby et al., 2006).

\section{Interval (range)}

The interval of concentrations employed to construct the analytical curve was evaluated by determining the precision (RSD, \%) and accuracy (E, \%) for diluted solutions of the standard pyrogallic acid (Fabre et al., 1993; ICH Q2B, 1995; FDA, 2000; Brasil, 2003).

\section{Estimated detection limit (LOD) and estimated quantification limit (LOQ)}

Detection limit and quantification limit were estimated by the slope and mean standard deviation of concentrations employed to construct the analytical curve, according to Equation 2 and Equation 3 (Green, 1996; ICH Q2B, 1995; Jenke, 1996; USP, 2003; FDA, 2001; Brasil, 2003):

$\mathrm{LOD}=\frac{3.3 \sigma}{\mathrm{S}}$

EQUATION 2 - Detection limit. $L O D$ is estimated detection limit $\left(\mu \mathrm{g} . \mathrm{mL}^{-1}\right) ; \sigma$ is mean standard deviation; $S$ is slope of the analytical curve.

$\mathrm{LOQ}=\frac{10 \sigma}{\mathrm{S}}$

EQUATION 3 - Quantification limit. $L O Q$ is estimated quantification limit $\left(\mu \mathrm{g} . \mathrm{mL}^{-1}\right) ; \sigma$ is mean standard deviation; $S$ is slope of the analytical curve.

\section{Precision and recovery/accuracy}

Precision was evaluated as the assessment of the closeness of the results obtained in a series of measurements of a multiple sampling of the same sample, and recovery/ accuracy represented the degree of match between the individual results found and a theoretical value accepted as reference (Brittain, 1998; Brasil, 2003; Shabir, 2003).

Precision and accuracy were calculated according to Equations 4 and 5, respectively:
$\operatorname{RSD}(\%)=\frac{\operatorname{SD} \times 100}{\mathrm{C}}$

EQUATION 4 - Precision. $R S D(\%)$ is precision; $S D$ is standard deviation; $C$ is mean of calculated concentrations.

Recovery/Accuracy $(\%)=\frac{\mathrm{C}_{\text {spiked }}-\mathrm{C}_{\text {extract }} \times 100}{\mathrm{TC}}$

EQUATION 5 - Recovery/Accuracy. $C_{\text {spiked }}$ is total polyphenols from extract spiked with standard; $C_{\text {extract }}$ is total polyphenols from extract; $T C$ is theoretical concentration of the standard reference (pyrogallic acid).

\section{RESULTS AND DISCUSSION}

Beyond the regulatory requirements, performance and reliability of analytical procedures are essential to the quality control of botanical raw materials. Based on the validation characteristics and necessities of guidelines presented on official and scientific literature, each analytical procedure must be validated with respect to parameters which are relevant to its performance. Parameters like linearity, range, specificity, precision, accuracy, limit of detection and limit of quantification are required to the experimental establishment of the validation process (Baby et al., 2006).

The method used to quantify total polyphenols, as pyrogallic acid equivalents, from Syzygium cumini (L.) Skeels fruit extract has offered linearity, over the concentration range of 0.25 to $7.5 \mu \mathrm{g} \cdot \mathrm{mL}^{-1}$. Through the visual analysis of the analytical curve, the plotted data of absorbance measurements at $757.0 \mathrm{~nm}$ versus range of the concentrations generated a straight line. The spectrophotometry used in this research work presented advantages for routine utilization as: simplicity, rapidity, sensitivity, equipment convenience and relative low cost of reagents.

Besides the visual analysis of the analytical curve, the least-squares fit method was employed to achieve the linearity, as statistical tool, reported at Table I. The regression line with corresponding coefficient of linear correlation $\left(\mathrm{r}^{2}\right)$ were $y=0.1744 \pm 0.0055) x+0.032( \pm 0.0034)$ and $\mathrm{r}^{2}=0.9979 \pm$ 0.0010 ), where: $y$ is absorbance and $x$ is total polyphenols concentration $\left(\mu \mathrm{g} \cdot \mathrm{mL}^{-1}\right)$. Statistical data were exposed with their respective standard deviation $\pm \mathrm{SD}$ ).

The results of the precision assay (RSD, \%) were reported at Table II for the total polyphenols and the polyphenols not-absorbed by the skin powder for the $S$. cumini (L.) Skeels extract.

The methods demonstrated a RSD inferior than $5.0 \%$, indicating an adequate precision for all assays (Brasil, 2003). 
Recovery/accuracy data were described at Tables III and IV. It was observed a greater percentage of recovery/ accuracy for the lowest concentrations of pyrogallic acid, indicating a positive correlation with that one of the extract.

The proposed method was considered accurate, as the recovery found in it totalizes the concentrations studied and showed adequate to the quantitative analysis of the extract and the standard pyrogallic acid.

After the validation of the methodology, the determination of the total polyphenols present on the extract was $27.706 \%$.

LOD and LOQ were estimated according to the standard curve deviation and the slope of the regression line, presented at Table V. Limit values were found to be 0.21 and $0.64 \mu \mathrm{g} . \mathrm{mL}^{-1}$, respectively, for LOD and LOQ. Agreeing with the study interval and the accuracy obtained for the theoretical concentrations of the standard pyrogallic acid, LOQ should present a value $>0.50 \mu \mathrm{g} \cdot \mathrm{mL}^{-1}$, which corroborated the estimated value of $0.64 \mu \mathrm{g} \mathrm{mL}^{-1}$.
TABLE I - Linearity statistical data and interval study

\begin{tabular}{lccc}
\hline $\begin{array}{l}\text { Total polyphenols } \\
\left(\mu \mathrm{g} \cdot \mathrm{mL}^{-1}\right)^{\mathrm{a}}\end{array}$ & $\mathrm{A} \pm \mathrm{SD}$ & $\mathrm{RSD}$ & $\mathrm{E}$ \\
\hline 0.25 & $0.0515 \pm 0.000837$ & 1.62 & 44.24 \\
0.50 & $0.1003 \pm 0.002623$ & 2.61 & 78.00 \\
1.00 & $0.2074 \pm 0.003732$ & 1.80 & 100.46 \\
2.00 & $0.3925 \pm 0.016529$ & 4.21 & 101.06 \\
2.50 & $0.4836 \pm 0.023877$ & 4.94 & 103.53 \\
3.00 & $0.5720 \pm 0.025572$ & 4.47 & 109.84 \\
4.00 & $0.7456 \pm 0.028502$ & 3.82 & 102.26 \\
5.00 & $0.9182 \pm 0.029043$ & 3.16 & 101.61 \\
7.50 & $1.3101 \pm 0.036485$ & 2.78 & 97.14 \\
\hline
\end{tabular}

${ }^{a}$ Theoretical concentrations; $\mathrm{A} \pm \mathrm{SD}$ : mean absorbance \pm standard deviation $(\mathrm{n}=8)$; RSD: precision, as relative standard deviation, \%; E: accuracy, \%.

TABLE II - Precision, as RSD\%, for the total polyphenols, as pyrogallic acid equivalents, and for the polyphenols not-absorbed by the skin powder

\begin{tabular}{lcccc}
\hline \multirow{2}{*}{ Days of analysis } & \multicolumn{2}{c}{ Total polyphenols, as pyrogallic acid } & \multicolumn{2}{c}{ Polyphenols not-absorbed by the skin powder } \\
& Mean \pm SD & RSD $\%$ & Mean \pm SD & RSD $\%$ \\
\hline 1 & $1.011273 \pm 0.018048$ & 1.784658 & $0.229662 \pm 0.006657$ & 2.898574 \\
2 & $1.022433 \pm 0.017558$ & 1.717285 & $0.245913 \pm 0.007012$ & 2.851468 \\
3 & $0.985198 \pm 0.02237$ & 2.27061 & $0.24612 \pm 0.007182$ & 2.918171 \\
Total & $1.006302 \pm 0.002648$ & 0.263156 & $0.240565 \pm 0.000268$ & 0.111416 \\
\hline
\end{tabular}

Mean \pm SD: mean of total polyphenols concentrations $(n=3) \pm$ Square Deviation

TABLE III - Recovery/accuracy for the total polyphenols, as pyrogallic acid equivalents, presented in the Syzygium cumini (L.) Skeels extract

\begin{tabular}{lcccc}
\hline $\begin{array}{l}\text { Standard added } \\
\left(\mu \mathrm{g} . \mathrm{mL}^{-1}\right)\end{array}$ & Extract spiked & Extract sample & $\begin{array}{c}\text { Pyrogallic acid } \\
\text { concentration found }\end{array}$ & $\begin{array}{c}\text { Recovery/ } \\
\text { Accuracy }(\%)\end{array}$ \\
\hline 1.0 & $1.225367 \pm 0.077878$ & $1.006302 \pm 0.002648$ & $0.207022 \pm 0.003687$ & 105.81725 \\
2.0 & $1.422556 \pm 0.082112$ & $1.006302 \pm 0.002648$ & $0.391668 \pm 0.015681$ & 106.2772 \\
3.0 & $1.573678 \pm 0.090506$ & $1.006302 \pm 0.002648$ & $0.571703 \pm 0.02394$ & 99.24313 \\
\hline
\end{tabular}

TABLE IV - Recovery/accuracy for polyphenols not-absorbed by the skin powder presented in the Syzygium cumini (L.) Skeels extract

\begin{tabular}{lcccc}
\hline $\begin{array}{l}\text { Standard added } \\
\left(\mu \mathrm{g} . \mathrm{mL}^{-1}\right)\end{array}$ & Extract spiked & Extract sample & $\begin{array}{c}\text { Pyrogallic acid } \\
\text { concentration found }\end{array}$ & $\begin{array}{c}\text { Recovery/ } \\
\text { Accuracy }(\%)\end{array}$ \\
\hline 1.0 & $0.451542 \pm 0.030494$ & $0.229662 \pm 0.006657$ & $0.207022 \pm 0.003687$ & 107.17701 \\
2.0 & $0.622797 \pm 0.037218$ & $0.2459 \pm 0.007012$ & $0.391668 \pm 0.015681$ & 96.228693 \\
3.0 & $0.82463 \pm 0.053287$ & $0.24612 \pm 0.007182$ & $0.571703 \pm 0.02394$ & 101.19065 \\
\hline
\end{tabular}


TABLE V - Estimative of limits of detection and quantification from standard curve deviation

\begin{tabular}{lccccc}
\hline $\begin{array}{l}\text { Total polyphenols } \\
\left.(\mu \mathrm{g} \mathrm{mL})^{-1}\right)^{\mathrm{a}}\end{array}$ & $\mathrm{SD}$ & $\sigma$ & $\mathrm{S}$ & LOD & LOQ \\
\hline 0.25 & 0.000837 & & & & \\
0.50 & 0.002623 & & & & \\
1.00 & 0.003731 & & & & \\
2.00 & 0.016529 & & & & \\
2.50 & 0.023877 & 0.011242 & 0.1744 & 0.21 & 0.64 \\
3.00 & 0.025572 & & & & \\
4.00 & 0.028502 & & & & \\
5.00 & 0.029043 & & & & \\
7.50 & 0.036485 & & & & \\
\hline
\end{tabular}

${ }^{a}$ Theoretical concentrations; SD: standard deviation; $\sigma$ : mean standard deviation; S: slope from the regression line; LOD: estimated limit of detection, $\mu \mathrm{g} \cdot \mathrm{mL}^{-1}(\mathrm{LOD}=3.3 \sigma / \mathrm{S})$; LOQ: estimated limit of quantification, $\mu \mathrm{g} \mathrm{mL}^{-1}(\mathrm{LOQ}=10 \sigma / \mathrm{S})$

\section{CONCLUSION}

A routine and economical spectrophotometric method was developed and validated for assay of total polyphenols, as pyrogallic equivalents, present in the Syzygium cumini (L.) Skeels extract. Method advantages were the absence of sample extraction, rapidity, direct responses and results, equipment convenience and relative low cost of reagents. The experimental results, in addition to statistical analysis, have proven that analytical parameters were precise, accurate and sensitive according to adequate linearity, recovery, repeatability and reproducibility, LOD and LOQ.

\section{ACKNOWLEDGEMENTS}

This work was supported by CAPES-Brasília, CNPq-Brasília and PADC-FCF-Araraquara.

\section{REFERENCES}

BABY,A.R.; MACIEL, C.P.M.; KANEKO, T.M.; VELASCO, M.V.R. UV spectrophotometric determination of bioflavonoids from a semisolid pharmaceutical dosage form containing Trichilia catigua Adr. Juss (and) Ptychopetalum olacoides Bentham standardized extract: analytical method validation and statistical procedures. J. AOAC Int., v.89, n.6, p.1532-1537, 2006.
BEER, J.O.; BATEN, P.; NSENGYUMVA, C.; SMEYERSVERBEKE, J. Measurement uncertainty from validation and duplicate analysis results in HPLC analysis of multivitamin preparations and nutrients with different galenic forms. $J$. Pharm. Biomed. Anal., v.32, n.4/5, p.767-811, 2003.

BRAGA, F.G.; BOUZADA, M.L.M.; FABRI, R.L.; MATOS, M.O.; MOREIRA, F.O.; SCIO, E.; COIMBRA, E.S. Antileishmanial and antifungal activity of plants used in traditional medicine in Brazil. J. Ethnopharmacol., v.111, n.2, p.396-402, 2007.

BRASIL. Resolução R.E. n. 899, de 29 de maio de 2003. Determina a publicação do Guia para validação de métodos analíticos e bioanalíticos. Available at: $<$ http://e-legis.bvs. br/leisref/public/showAct.php?id=15132\&word $>$. Access on: 26 Jan. 2004.

BRITTAIN, H.G. Validação de métodos analíticos não cromatográficos. Pharm. Technol., Ed. Bras., São Paulo, v.2, n.3, p.4-9, 1998.

CAUSON, R. Validation of chromatographic methods in biomedical analysis: view point and discussion. $J$. Chromatogr. B. Biomed. Sci. Appl., v.689, n.1, p.175-180, 1997.

CHANDRASEKARAN, M.; VENKATESALU, V. Antibacterial and antifungal activity of Syzygium jambolanum seeds. J. Ethnopharmacol., v.91, n.1, p.105-108, 2004.

FABRE, H.; SUN, S.W.; MANDROU, B.; MAILLOLS, H. Assay validation for an active ingredient in pharmaceutical formulation: practical approach using ultraviolet spectrophotometry. Analyst Letchworth., v.118, n.4, p.10611064, 1993.

FARMACOPÉIA Brasileira. 4.ed. São Paulo: Atheneu. 1988. $\mathrm{pt} 1$.

FDA. Food and Drug Administration. Center for Drug Evaluation and Research. Chemistry (Draft). Analytical procedures and methods validation: chemistry, manufacturing and controls documentation. 2000. Available at: http://www.fda.gov/ cder/guidance/. Acess on: 12 Nov. 2005.

FDA. Food and Drug Administration. Center for Drug Evaluation and Research. Biopharmaceutics. Bioanalytical method validation. 2001. Available at: http://www.fda.gov/ cder/guidance. Acess on: 12 Nov. 2005. 
GREEN, J.M. A practical guide to analytical method validation. Anal. Chem., Columbus, v.68, p.305-309, 1996. Available at: http://www.pubs.acs.org. Acess on: 12 Jun. 2004.

GROVER, J.K.; VATS, V.; RATHI, S.S.; DAWAR, R. Traditional Indian anti-diabetic plants attenuate progression of renal damage in streptozotocin induced diabetic mice. $J$. Ethnophamacol., v.76, n.3, p.233-238, 2001.

ICH Q2B. Department of Health and Human Services. Food and Drug Administration. Center for Drug Evaluation Research. Guidance for industry: ICH Q2B Validation of analytical procedures: methodology. Rockville, 1995. (CPMP/ ICH/281/95). Available at: http://www.fda.gov/cber/gdlns/ ichq2bmeth.pdf. Acess on: 26 Jan. 2008.

JENKE, D.R. Chromatographic method validation: a review of current practices and procedures. II. Guidelines for primary validation parameters. J. Liq. Chromatogr. Relat. Technol., v.19, n.5, p.737-757, 1996.

MIGLIATO, K.F.; BABY, A.R.; ZAGUE, V.; VELASCO, M.V.R.; CORRÊA, M.A.; SACRAMENTO, L.V.S.; SALGADO, H.R.N. Ação farmacológica de Syzygium cumini (L.) Skeels. Acta Farm. Bonaer., v.25, n.2, p.310304, 2006.

MIGLIATO, K.F.; MOREIRA, R.R.D.; MELLO, J.C.P.; SACRAMENTO, L.V.S.; CORRÊA, M.A.; SALGADO, H.R.N. Controle da qualidade do fruto de Syzygium cumini (L.) Skeels. Rev. Bras. Farmacogn., v.17, n.1, p.94-101, 2007.

MULHOLLAND, M.; HIBBERT, D.B. Linearity and the limitations of squares calibration. J. Chromatogr., v.762, n.1/2, p.73-82, 1997.

PEPATO, M.T, MORI, D.M.; BAVIERA, J.B.; HARAMI, R.C.; VENDRAMINI, R.; BRUNETTI, I.L. Fruit of the jambolan tree (Eugenia jambolana Lam.) and experimental diabetes. J. Ethnopharmacol., v.96, n.1-2, p.43-48, 2004.
REYNERTSON, K.A.; YANG, H.; JIANG, B.; BASILE, M.J.; KENNELLY, M.E.J. Quantitative analysis of antiradical phenolic constituents from fourteen edible Myrtaceae fruits, Food Chem., v.109, n.4, p. 883-890, 2008.

ROLIM,A.; MACIEL, C.P.M.; KANEKO, T.M.; CONSIGLIERI, V.O.; SALGADO-SANTOS, I.M.N.; VELASCO, M.V.R. Validation assay for total flavonoids, as rutin equivalents, from Trichilia catigua Adr. Juss (Meliaceae) and Ptychopetalum olacoides Bentham (Olacaceae) commercial extract. J. AOAC Int., v.88, n.4, p.1015-1019, 2005.

SCALBERT, A. Antimicrobial properties of tannins. Phytochem. Anal, v.30, n.12, p.3875-1883, 1991.

SHABIR, G.A. Validation of high-performance liquid chromatography methods for pharmaceutical analysis. Understanding the differences and similarities between validation requirements of the US Food and Drug Administration, the US Pharmacopeia and the International Conference on Harmonization. J. Chromatogr. A, v.987, n.1-2, p.57-66, 2003.

SHAFI, P.M.; ROSAMMA, M.K.; JAMIL, K.; REDDY, P.S. Antibacterial activity of Syzygium cumini and Syzygium travancoricum leaf essential oils. Fitoterapia, v.73, n.5, p.414-416, 2002.

SHARMA, S.B.; NASIR, A.; PRABHU, K.M.; MURTHY, P.S.; DEV, G. Hypoglycaemic and hypolipidemic effect of ethanolic extract of seeds of Eugenia jambolana in alloxaninduced diabetic rabbits. J. Ethnopharmacol., v.85, n.2-3, p.201-206, 2003.

UNITED States Pharmacopeia. 27 ed. The National Formulary: NF22. Rockville: United States Pharmacopeial Convention, 2003. p.2622-2625.

Recebido para publicação em 28 de março de 2008. Aceito para publicação em 27 de agosto de 2008. 